\title{
Nuclear Pore Flow Rate of Ribosomal RNA and Chain Growth Rate of Its Precursor during Oogenesis of Xenopus laevis ${ }^{1}$
}

\author{
UlRICH ScheER \\ Department of Cell Biology, Institute of Biology II, University of Freiburg i.Br., D-78 Freiburg, Germany
}

Accepted June 12, 1972

\begin{abstract}
The number of ribosomal RNA molecules which are transferred through an average nuclear pore complex per minute into the cytoplasm (nuclear pore flow rate, NPFR) during oocyte growth of Xenopus laevis is estimated. The NPFR calculations are based on determinations of the increase of cytoplasmic rRNA content during defined time intervals and of the total number of pore complexes in the respective oogenesis stages. In the mid-lampbrush stage $(500-700 \mu \mathrm{m}$ oocyte diameter) the NPFR is maximal with $2.62 \mathrm{rRNA}$ molecules/pore/minute. Then it decreases to zero at the end of oogenesis. The nucleocytoplasmic RNA flow rates determined are compared with corresponding values of other cell types. The molecular weight of the rRNA precursor transcribed in the extrachromosomal nucleoli of Xenopus lampbrush stage oocytes is determined by acrylamide gel electrophoresis to be $2.5 \times 10^{6}$ daltons. From the temporal increase of cytoplasmic rRNA ( $3.8 \mu \mathrm{g}$ per oocyte in 38 days) and the known number of simultaneously growing precursor molecules in the nucleus the chain growth rate of the $40 \mathrm{~S}$ precursor RNA is estimated to be 34 nucleotides per second.
\end{abstract}

\section{INTRODUCTION}

The prolonged diplotene stage of the meiotic prophase during amphibian oogenesis ("vegetative phase" in the sense of Raven, 1961) is characterized by an intense accumulation of material which is essential for future embryonic growth and differentiation. Yolk platelets and ribosomes are the two quantitatively dominant products which are stored in the growing oocyte (for an extensive review see Wischnitzer, 1966). While the yolk protein is synthesized in the liver and selectively taken up by the oocytes from the circulation as a Ca-lipophosphoprotein complex (e.g., Wallace and Dumont, 1968; Wallace and Jared, 1969; Jared and Wallace, 1970; Wallace, 1970), there is no indication for extraoocyte production of RNA and subsequent transfer to the oocyte in amphibians (Brown, 1966; see also Panje and Kessel, 1968). On the contrary, the

${ }^{1}$ This article is No. $\mathrm{V}$ in the series: The Ultrastructure of the Nuclear Envelope of Amphibian Oocytes. germinal vesicle of an amphibian oocyte is specialized to synthesize ribosomal RNA (rRNA) at a very high rate due to the specific amplification of the genes coding for $18 \mathrm{~S}$ and $28 \mathrm{~S}$ rRNAs (e.g., Brown and Dawid, 1968). The increased capacity of the oocyte genome to transcribe the rRNA molecules is consistent with the results of Davidson and associates who have reported that as much as $90-98 \%$ of the RNA synthesized per unit time in the lampbrush stage of the Xenopus oogenesis is rRNA (Davidson et al., 1964, 1966). The mature Xenopus egg shows a corresponding stationary RNA distribution: over $90 \%$ of the egg RNA consists of $18 \mathrm{~S}$ and $28 \mathrm{~S}$ ribosomal molecules (Mairy and Denis, 1971) which are primarily contained in inactive single ribosomes (Cox et al., 1970).

Since most if not all of the rRNA synthesized during oogenesis is conserved at least until the ovulation of the egg (Brown, 1964; Brown and Littna, 1964b; Davidson et al., 1964), the number of both the high molecular weight rRNA molecules 
transported from nucleus to cytoplasm could be calculated from measurements of the increase of the total acid-insoluble cytoplasmic RNA content during a certain oogenesis interval. It is a widely accepted concept that this nucleocytoplasmic efflux is mediated by the nuclear pore complexes. Some general ultrastructural aspects of the nuclear pore complex transport mechanisms in the amphibian oocyte have been presented in previous communications of our and other laboratories (e.g., Pollister et al., 1954; Miller, 1962; Balinsky and Devis, 1963; Takamoto, 1966; Lane, 1967; Clerot, 1968; Massover, 1968; Cole, 1969; Kessel, 1969; Franke and Scheer, 1970b; Eddy and Ito, 1971). Knowing the total number of nuclear pore complexes in a specific oogenesis phase, it should thus be possible to determine the rRNA translocation capacity of an average nuclear pore complex. Such a transport function can be quantitatively expressed by the "nuclear pore flow rate" (NPFR), a term introduced by Franke (1970): it means the total mass or number of molecules of a certain substance which is transferred through an average pore per minute. In the present paper it will be shown that during Xenopus oogenesis marked differences exist in the rRNA "nuclear pore flow rates" from nucleoplasm to cytoplasm.

Furthermore, from the temporal increase of rRNA in an actively growing oocyte the number of newly synthesized ribosomes and, consequently, of the minimum number of precursor rRNA (pre-rRNA) molecules transcribed during a certain time interval was estimated. The molecular weight of these pre-rRNA molecules synthesized in the extrachromosomal nucleoli was determined by acrylamide gel electrophoresis and thus allowed a rough calculation of their chain growth rates since the total number of simultaneously growing pre-rRNA mole- cules in a lampbrush-stage Xenopus oocyte is known (Miller and Beatty, 1969).

\section{MATERIALS AND METHODS}

RNA determination. An adult Xenopus laevis female was anesthesized in $0.1 \%$ MS 222 (Fa. Sandoz, Basel, Switzerland); parts of the ovaries were removed and placed in amphibian Ringer solution. Seven oocyte classes with diameters ranging from 300 to $1200 \mu \mathrm{m}$ were selected, the surrounding follicle epithelium was manually removed with forceps, and the oocytes were collected in ice-cold absolute ethanol.

According to Davidson et al. (1964), the lampbrush phase in Xenopus, i.e., the stage at which most of the RNA present in the mature egg is synthesized, is found in oocytes of diameters from 400 to 800 $\mu \mathrm{m}$. However, according to Ficq (1968) loop extension of the chromosomes has already begun in oocytes of $150 \mu \mathrm{m}$ diameter. The end of the lampbrush phase, as characterized by contraction of the loops and simultaneous migration of the nucleoli from the nuclear periphery into the center of the germinal vesicle, has been found to occur in Xenopus oocytes with a diameter of 1000-1100 $\mu \mathrm{m}$. Mature oocytes with a diameter of $1200 \mu \mathrm{m}$ show a white equatorial band and are inactive in RNA synthesis.

For the RNA determinations of one oocyte class, 3-30 oocytes, depending on their size, were collected. The acid-soluble compounds were removed by washing the homogenized oocytes twice with $10 \%$ trichloroacetic acid (TCA) for $20 \mathrm{~min}$ each at $0^{\circ} \mathrm{C}$. The pellet obtained after centrifugation at $0-2{ }^{\circ} \mathrm{C}$ for $10 \mathrm{~min}$ at $2800 \mathrm{~g}$ was suspended in chloroformmethanol $(1: 2, \mathrm{v} / \mathrm{v})$ for $15 \mathrm{~min}$ at room temperature, centrifuged, and resuspended in chloroform-methanol (2:1) for $15 \mathrm{~min}$. After centrifugation, the supernatant was removed, the pellet was dried in a desiccator and then suspended 
in $1.6 \mathrm{ml}$ SSC buffer $(\mathrm{pH} 7.2)$. Then 0.4 $\mathrm{ml}$ pronase $(5 \mathrm{mg} / \mathrm{ml}$, Calbiochem, B grade) and $0.1 \mathrm{ml} 10 \%$ SDS were added, and the solution was incubated for $12 \mathrm{hr}$ at $37^{\circ} \mathrm{C}$. Prior to use, the pronase solution was heated to $80^{\circ} \mathrm{C}$ for $10 \mathrm{~min}$ at $\mathrm{pH} 5$ to remove DNase activities (cf. Hotta and Bassel, 1965) and was subsequently predigested at $\mathrm{pH} 7.2$ for $1 \mathrm{hr}$ at $37^{\circ} \mathrm{C}$. After cooling to $0^{\circ} \mathrm{C}, 0.4 \mathrm{ml} 60 \%$ TCA was added. After $20 \mathrm{~min}$ the precipitate was centrifuged, and the pellet was washed twice with $10 \%$ cold TCA. The final residue was suspended in $1 \mathrm{ml} 0.4 \mathrm{~N} \mathrm{NaOH}$ and kept for $16 \mathrm{hr}$ at $37^{\circ} \mathrm{C}$. The solution was then cooled, and TCA was added to a final concentration of $10 \%$. After $20 \mathrm{~min}$ in the cold the solution was centrifuged and the supernatant, together with the supernatants of the two further washings of the pellet with 10\% TCA, was collected. The RNA hydrolyzate then was evaporated to dryness. The phosphorus (P) content was determined by the method of Gerlach and Deuticke (1963). The RNA content was calculated from the differences between the $\mathrm{P}$ content of the controls (same procedure without oocytes) and the samples, assuming a $\mathrm{P}$ content of RNA of $9 \%$.

To test a possible contamination of the alkaline hydrolyzate by phosphorus from yolk-derived phosphoprotein, oocytes were also enzymatically hydrolyzed with pretreated RNase $(0.4 \mathrm{mg} / \mathrm{ml}$, heated to $80^{\circ} \mathrm{C}$ for $10 \mathrm{~min}$ at $\mathrm{pH} 5$ prior to use): the TCA precipitate obtained after the pronase digestion was suspended in $1 \mathrm{ml}$ of SSC-buffered ( $\mathrm{pH}$ 7.2) RNase solution for $2 \mathrm{hr}$ at $37^{\circ} \mathrm{C}$. Control oocytes were treated in the same way but were then incubated in SSC buffer without RNase. The amount of RNA was calculated either from $\mathrm{P}$ determinations as outlined above or from optical density readings at 260 $\mathrm{nm}$. In these latter cases the RNA hydrolyzate was cooled and perchloric acid (PCA) was added to a final concentration of $0.3 \mathrm{~N}$. After two washings with $0.3 \mathrm{~N}$ PCA the optical density of the combined supernatants was measured. Adequate aliquots of yeast RNA were hydrolyzed in the same way and served as standards.

Duration of oocyte growth. Preliminary experiments to mark growing oocytes in situ with vital dyes were not successful since the individual oocytes could not be identified after weeks. Therefore, one ovary of an anesthesized animal was almost completely removed. Only small oocytes adhering to the rest of the mesovarium were left and their diameters were determined. The incision in the ventral body wall was stitched, and the animal received 300 IU of a human chorion gonadotropic hormone (Predalon, Fa. Organon, Munich, Germany). After defined time spans the animal was opened again and the oocytes were measured. Ten toads were treated in this way at five different time intervals.

Gel electrophoresis of RNA. Thirty lampbrush stage oocytes of Xenopus were incubated at $30^{\circ} \mathrm{C}$ in $0.5 \mathrm{ml}$ TC 199 (diluted $1: 1$ with distilled water) and containing $100 \mu \mathrm{Ci} / \mathrm{ml}{ }^{3} \mathrm{H}$-uridine (specific activity $27 \mathrm{Ci} / \mathrm{mmole}$; The Radiochemical Centre, Amersham, England). After $24 \mathrm{hr}$ the nuclei were manually isolated in the "5:1-medium" $(0.1 \mathrm{M} \mathrm{KCl}$ and $0.1 \mathrm{M}$ $\mathrm{NaCl}$ in a 5:1 ratio; Callan and Lloyd, 1960) and subsequently collected at $4^{\circ} \mathrm{C}$ in ethanol-acetic acid (3:1). The fixed nuclei were washed three times in cold $70 \%$ ethanol, dried, and then incubated for $2 \mathrm{hr}$ at $30^{\circ} \mathrm{C}$ in $0.5 \mathrm{ml} 0.02 \mathrm{M}$ Tris $\cdot \mathrm{HCl}$ ( $\mathrm{pH} 7.4$ ) containing $0.5 \%$ SDS and $1 \mathrm{mg} / \mathrm{ml}$ predigested pronase. After addition of 25 $\mu \mathrm{g}$ unlabeled carrier rRNA (isolated from a Xenopus ovary according to the method described in detail by Brown, 1967), the RNA was precipitated by adding $\mathrm{NaCl}$ to a final concentration of $0.1 \mathrm{M}$ and 2.5 volumes of cold absolute ethanol. The solution was held for several hours at $-20^{\circ} \mathrm{C}$. After centrifugation, the RNA pellet was 
dissolved in $10 \mu \mathrm{l}$ of electrophoresis buffer (0.02 $M$ Tris. $\mathrm{HCl}, \mathrm{pH} 8.0,0.02 M$ $\mathrm{NaCl}, 0.002 M$ EDTA) containing $0.2 \%$ SDS and was applied to the gel. Slabs of $2.25 \%$ acrylamide $-0.5 \%$ agarose composite gels were used for the electrophoretic separation. The preparation of the gel, the electrophoretic conditions, slicing the gel with parallel razor blades with $1.1 \mathrm{~mm}$ spacing, as well as the measurement of the radioactivity, were identical to the procedure described by Ringborg et al. (1970). The samples were counted in a Tri-Carb Packard scintillation spectrometer in the scintillator mixture given by these authors. The counts shown in Fig. 8 are uncorrected for quenching and background. The molecular weights for the labeled nuclear species were calculated by assuming a linear relationship between their electrophoretic mobility and the logarithm of the molecular weight. The molecular weights of the reference RNAs (18 S equivalent to $0.7 \times 10^{6}$ daltons, $28 \mathrm{~S}$ equivalent to $1.5 \times 10^{6} \mathrm{dal}$ tons) were taken from Loening et al. (1969).

\section{Electron microscopy.}

Negative staining. Isolation of an oocyte nucleus in the 5:1-medium, fixation of the nuclear envelope with $1 \%$ osmium tetroxide, and negative staining with neutralized phosphotungstic acid was carried out according to the methods previously described (Scheer and Franke, 1969; Franke and Scheer, 1970a).

Ultrathin sectioning. Oocytes were fixed in $4 \%$ cold glutaraldehyde buffered to $\mathrm{pH}$ 7.2 with $0.05 M$ sodium cacodylate for 2 $\mathrm{hr}$, washed thoroughly in the same buffer, and osmicated for $2 \mathrm{hr}$ with $1 \% \mathrm{OsO}_{4}(\mathrm{pH}$ $7.2)$ in the cold. The material was dehydrated through an ethanol series, embedded in Epon 812 and sectioned on a Reichert ultramicrotome OmU2. The sections were stained with uranyl acetate and lead citrate.

Freeze-etching. Oocytes were immersed stepwise at room temperature from $5 \%$ to
$25 \%$ glycerol dissolved in amphibian Ringer solution and then rapidly frozen in liquid Freon 22. The freeze-etching was performed as described elsewhere (Kartenbeck et al., 1971).

Electron micrographs were made with a Siemens Elmiskop IA. The magnification of the instrument was controlled with a grating replica (deviation below 5\%).

Cryotome sections. Freshly prepared Xenopus oocytes were embedded in small pieces of bovine liver, directly frozen in liquid Freon 22 without the use of antifreeze agents, and stored in liquid nitrogen. Sections $(10 \mu \mathrm{m})$ were cut on a cryotome (WK 1150, Fa. Weinkauf, Brandau, Germany) at $-25^{\circ} \mathrm{C}$ and were immediately photographed.

\section{RESULTS}

\section{RNA Determination of Different Oocyte Classes}

In order to test the specificity of the Schmidt-Thannhauser procedure used in the present study and further to check possible contaminations with yolk-derived phosphorus which would cause an overestimation of the RNA values, the results of the alkaline hydrolysis were compared with those of the enzymatic hydrolysis. The kinetics of the RNase action showed that the extraction was complete after 90 min. The RNA content of one mature Xenopus oocyte amounted to $4.26 \mu \mathrm{g}$ (RNase, P determination, 10 experiments with a standard error of $0.16 \mu \mathrm{g}$ ) and to $3.94 \mu \mathrm{g}$ (RNase, optical density at 260 $\mathrm{nm}, 10$ experiments with $\mathrm{SE}=0.20 \mu \mathrm{g})$ as compared to $4.18 \mu \mathrm{g}(\mathrm{SE}=0.17 \mu \mathrm{g})$ after $\mathrm{NaOH}$ hydrolysis and $\mathrm{P}$ determination (Table 1). Therefore, alkaline hydrolysis with subsequent $\mathrm{P}$ determination can be regarded as a sufficiently precise and sensitive method for measuring the RNA content of amphibian oocytes.

The total acid-insoluble RNA content of the different oocyte classes is presented 
in Table 1. These values differ somewhat from those reported by other authors (Davidson et al., 1964; Hanocq-Quertier et al., 1968; Mairy and Denis, 1971). This may be due to the different determination methods employed and also to variability in the biological material. Indeed, it was found that equal-sized oocytes of animals obtained from different sources showed distinct differences in their RNA content (compare also the values for mature Xenopus oocytes reported by Scheer, 1972). The values of Table 1 describe with good approximation the cytoplasmic increase of the $18 \mathrm{~S}$ and $28 \mathrm{~S}$ rRNAs during oogenesis, since the nucleus contains only about $0.5 \%$ of the total egg RNA in the mature oocyte (Scheer, 1972), and no more than ca. 5\% in the youngest stages examined. Furthermore, in the growing oocyte almost all the RNA synthesis is rRNA synthesis (e.g., Davidson et al., 1964).

In Fig. 1 the RNA content of different oocyte classes from Table 1 is plotted against the ooplasmic volume, i.e., the oocyte volume minus the nuclear volume (calculated from the data of Fig. 2). It can be seen that in the earlier stages of growth there is a relatively sharp increase of RNA whereas in later stages the RNA accumulation relative to the cytoplasmic growth becomes lower, possibly as a consequence of the deposition of yolk platelets (see also Osawa and Hayashi, 1953). Since the pro-

TABLE 1

Quantitative RNA Determination of Selected Xenopus Oocytes from Which The Follicle Cells Had Been Removed ${ }^{a}$

\begin{tabular}{ccc}
\hline $\begin{array}{c}\text { Oocyte diam- } \\
\text { eter } \\
(\mu \mathrm{m})\end{array}$ & $\begin{array}{c}\text { RNA content } \\
\text { per oocyte } \\
(\mu \mathrm{g})\end{array}$ & $\begin{array}{c}\text { Standard error } \\
(\mu \mathrm{g})\end{array}$ \\
\hline 300 & 0.125 & 0.05 \\
400 & 0.377 & 0.08 \\
500 & 0.910 & 0.07 \\
700 & 1.914 & 0.11 \\
900 & 2.864 & 0.12 \\
1100 & 3.891 & 0.15 \\
1200 & 4.180 & 0.17 \\
\hline
\end{tabular}

${ }^{a}$ Each value is based on 5 determinations. gressive accumulation of yolk augments the cytoplasmic volume without or with only little (Kelley et al., 1970) concomitant RNA increase, the cytoplasmic RNA concentration falls during the vitellogenic phase of oogenesis (Fig. 1).

\section{Temporal Sequence of Oocyte Growth}

In the literature there exist only very vague data about the duration of specific oogenesis phases in amphibians (e.g., Grant, 1953; Wischnitzer, 1966). According to Gall and Callan (1962) and Callan (1963) the lampbrush stage in Triturus cristatus takes about 7 mo. The same period lasts ca. $1.5 \mathrm{mo}$ in the tropical frog Engystomops pustulosis (Davidson, 1968). The only statement about the growth rate of Xenopus oocytes was found in Davidson's book (1968): the increase from 400 to $800 \mu \mathrm{m}$ oocyte diameter requires 4-8 mo.

In contrast, the results of the surgical experiments show that the oocyte development, at least under the specific conditions of partial ovariectomy and chorion gonadotropic hormone stimulation, can be a much shorter process (Fig. 3). It should be emphasized that the diagram of Fig. 3 represents, with all probability, the maximal oocyte growth rate which occurs under natural conditions only after oviposition.

Combining the values of Table 1 and of Fig. 3 it is possible to demonstrate the temporal increase of the RNA content in the growing oocyte (Fig. 4). During early lampbrush stages $(300-400 \mu \mathrm{m}$ oocyte diameter) RNA production increases only moderately, whereas oocytes with a diameter more than $400 \mu \mathrm{m}$ accumulate rRNA with a higher and almost constant rate.

\section{Structural Data of the Nuclear Envelope during Oogenesis}

The values of the pore diameter and pore frequency as summarized in Table 2 were obtained from a great number of negative staining preparations (Fig. 6), freezeetch replicas (Fig. 5), and ultrathin sec- 


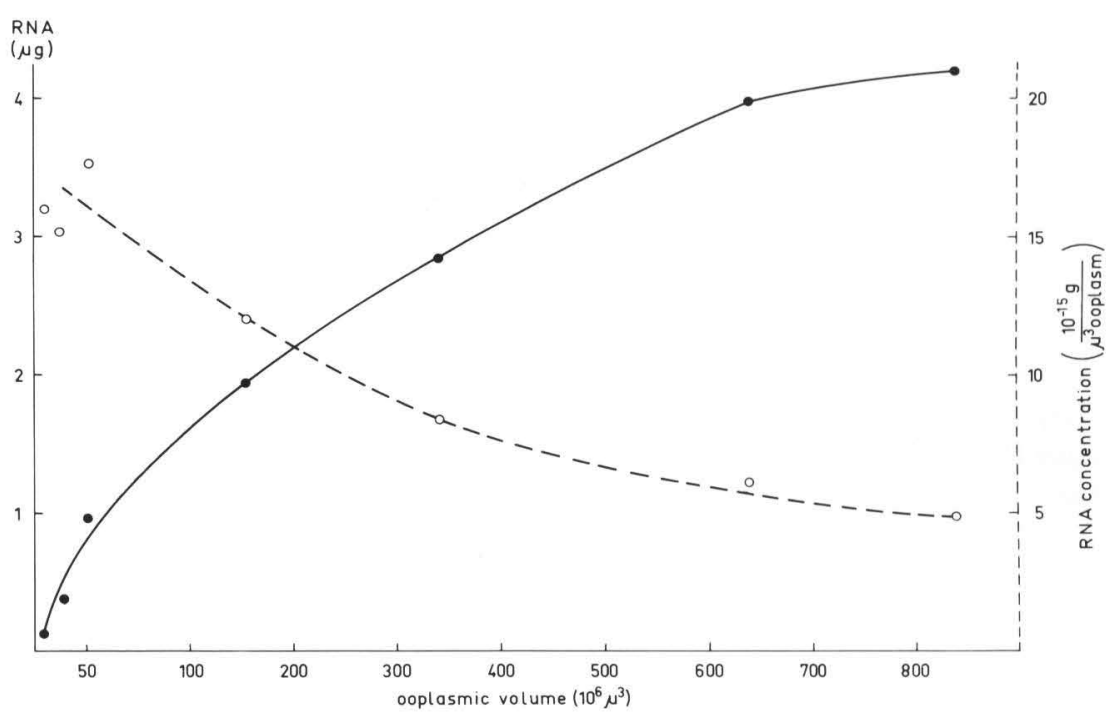

FIG. 1. Absolute cytoplasmic RNA content (-) and RNA concentration (----) of Xenopus laevis oocytes during different growth stages.

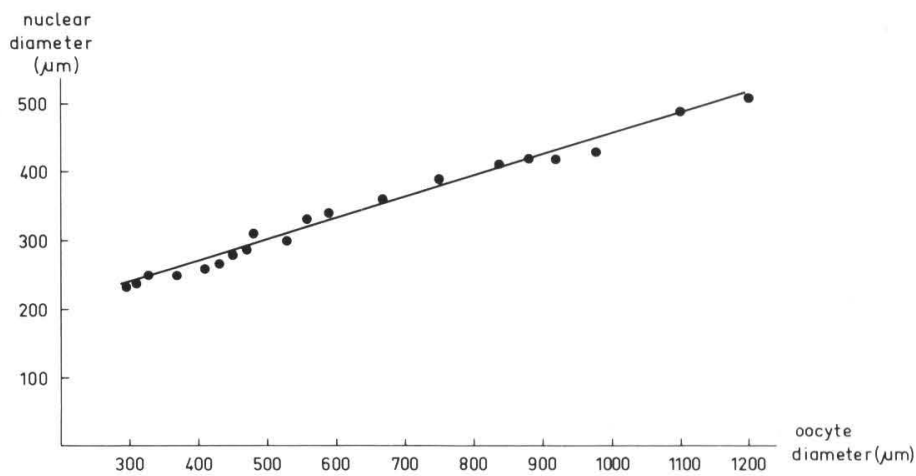

FIG. 2. Correlation of oocyte and nuclear diameter during oogenesis of Xenopus laevis.

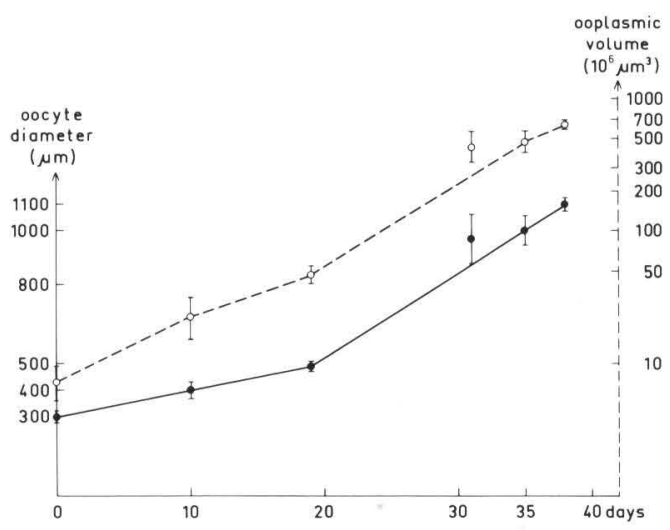

Fig. 3. Oocyte growth of Xenopus laevis after partial ovariectomy and hormone stimulation. Increase of the oocyte diameter ( $\longrightarrow$ ) and of the ooplas- tions tangential to nuclear envelope (cf. Franke and Scheer, 1970a,b; Kartenbeck et al., 1971). All three different electron microscopic preparative methods gave nearly identical data (for a detailed methodical discussion see Kartenbeck et al., 1971), thus allowing the conclusion that the quantitative structural data of the nuclear envelope are unaffected by methodical artifacts. In this connection it should be

mic volume (total oocyte volume minus nuclear volume, -----). Each point represents the mean of 5-10 measurements and is given with the standard deviation. 


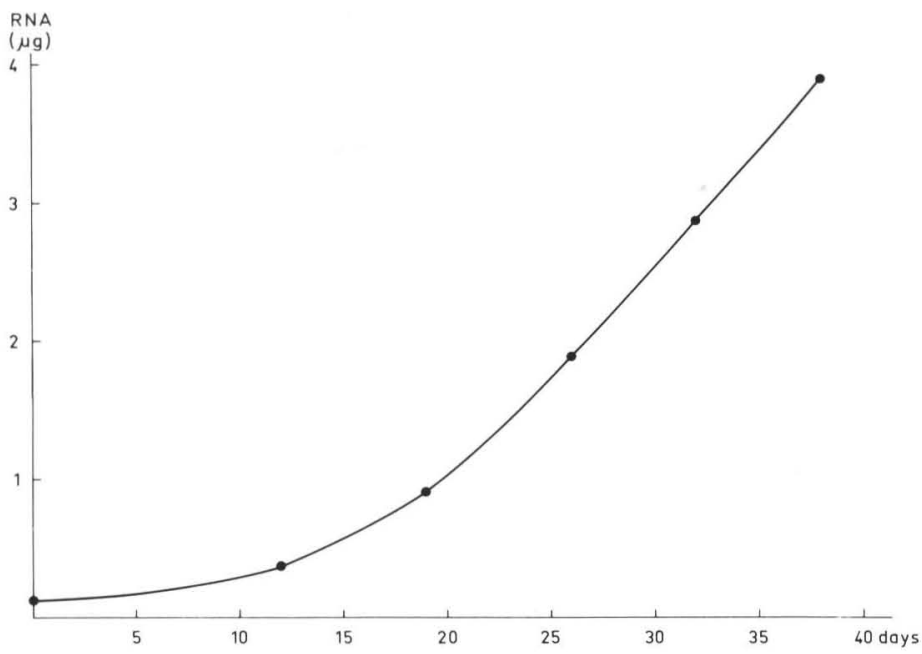

Fig. 4. Accumulation of ribosomal RNA in the cytoplasm of an oocyte of Xenopus laevis during the growth interval from 300 to $1100 \mu \mathrm{m}$ oocyte diameter.

TABLE 2

Some Quantitative Data on the Nuclear Envelope during Oocyte Development in Xenopus laevis

\begin{tabular}{cccccc}
\hline $\begin{array}{c}\text { Ooctye diam- } \\
\text { eter } \\
(\mu \mathrm{m})^{a}\end{array}$ & $\begin{array}{c}\text { Pore diameter } \\
(\AA)\end{array}$ & $\begin{array}{c}\text { Pore frequency } \\
(\text { No. of pores } \\
\left.\text { per } \mu^{2}\right)\end{array}$ & $\begin{array}{c}\text { Percentage } \\
\text { of nuclear } \\
\text { surface } \\
\text { occupied by } \\
\text { pore area }\end{array}$ & $\begin{array}{c}\text { Total nuclear } \\
\text { surface } \\
\left(\mu^{2}\right)\end{array}$ & $\begin{array}{c}\text { Total } \\
\text { number of } \\
\text { nuclear pore } \\
\text { complexes } \\
\left(\times 10^{6}\right)\end{array}$ \\
\hline 300 & $680 \pm 23(123)$ & $58 \pm 4.0(16)$ & 21.1 & 173,495 & 10.06 \\
400 & $748 \pm 21(142)$ & $63 \pm 4.4(35)$ & 27.7 & 229,023 & 14.43 \\
500 & $743 \pm 33(107)$ & $61 \pm 8.3(21)$ & 26.4 & 292,247 & 17.83 \\
$7 C 0$ & $725 \pm 28(233)$ & $58 \pm 6.6(23)$ & 23.9 & 407,151 & 23.61 \\
900 & $762 \pm 24(140)$ & $56 \pm 5.2(19)$ & 25.5 & 567,451 & 31.78 \\
1100 & $753 \pm 24(301)$ & $51 \pm 8.4(24)$ & 22.7 & 738,983 & 37.69 \\
1200 & $763 \pm 23(170)$ & $47 \pm 3.3(18)$ & 21.5 & 801,187 & 37.70 \\
\hline
\end{tabular}

${ }^{a}$ These oocytes were selected by size with a maximal tolerance of $\pm 25 \mu \mathrm{m}$.

${ }^{b}$ The values are given with the standard deviation; the number of measurements is given in parentheses.

${ }^{c}$ The values are given with the standard deviation; the square microns of evaluated nuclear surface are given in parentheses.

emphasized that the isolated nucleus showed no swelling during the isolation (for the negative stain preparations) since care was taken that the whole procedure from tearing off the oocyte to fixation of the nuclear envelope attached to the Formvar-coated grid lasted no longer than ca. 30 sec. It is obvious from Table 2 that, during the interval of oogenesis investigated, the average pore diameter (ca. $740 \AA$ ) and the average pore frequency (57 pores per square micron) is relatively constant. Consequently, the relative pore area, i.e., the portion of the pore area in relation to the total nuclear surface, shows only minor modulations and lies between $21 \%$ and $28 \%$ (Table 2 ).

The total nuclear surface area was computed using the nuclear diameter values of Fig. 2 with the assumption that the nuclear surface is spherical. ${ }^{2}$ Some observa-

\footnotetext{
${ }^{2}$ These values of nuclear diameters relative to oocyte diameters differ somewhat from those reported by Peterson (1971) for several amphibian species, perhaps because this author used paraffin sections through oocytes.
} 


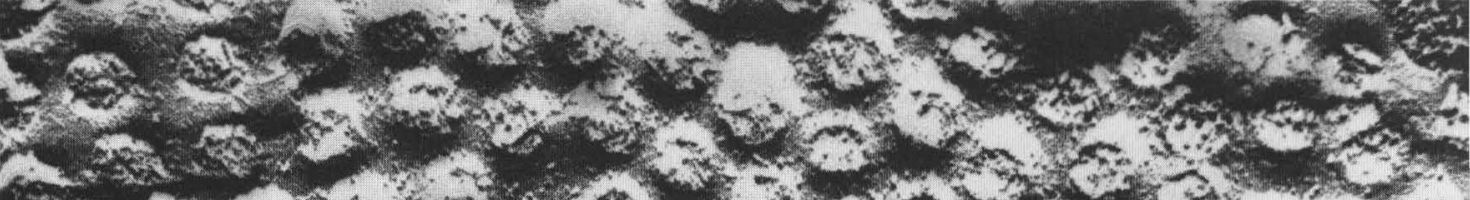

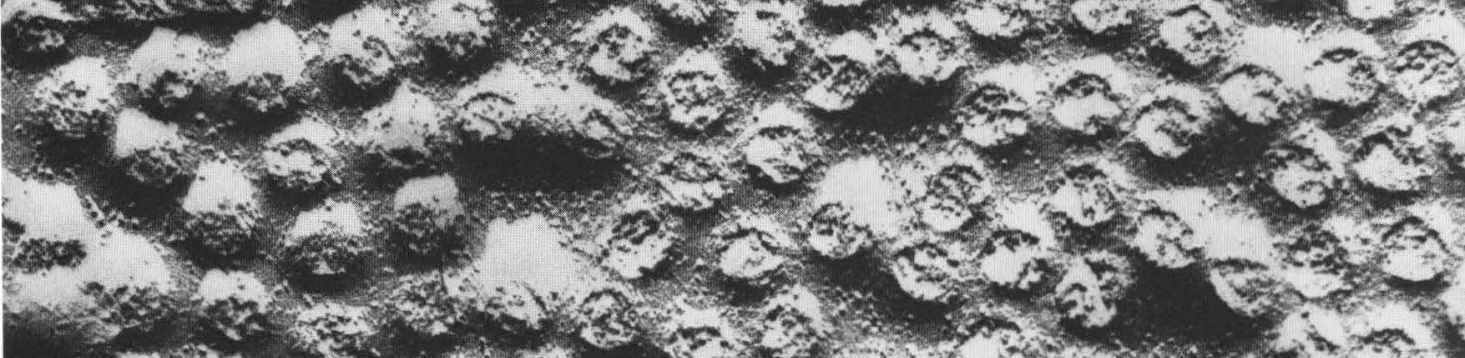

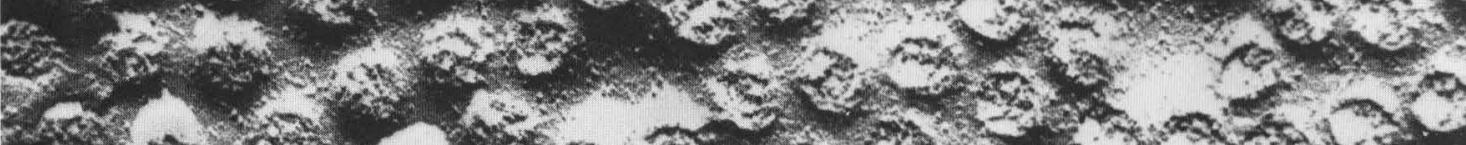

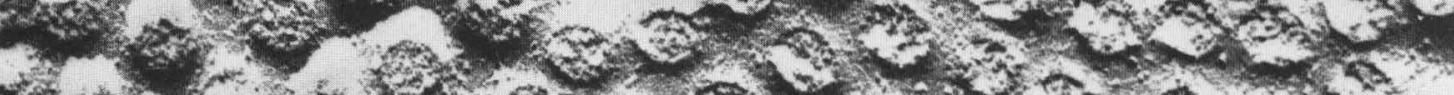

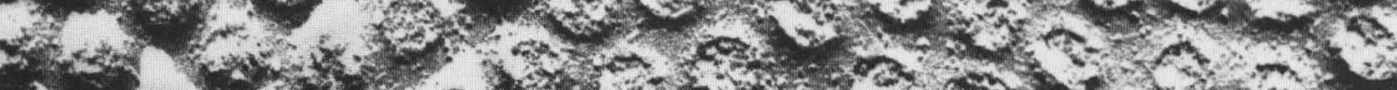

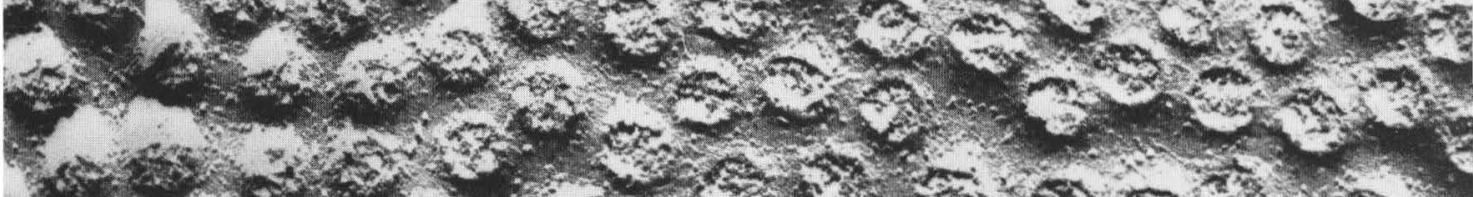

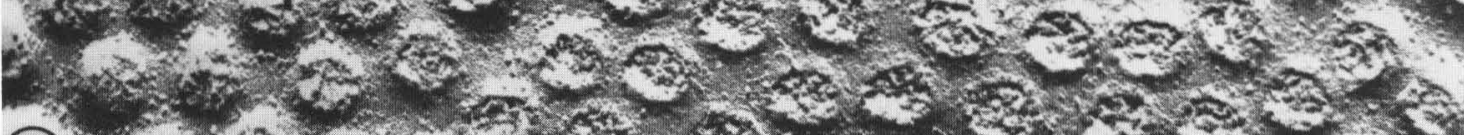

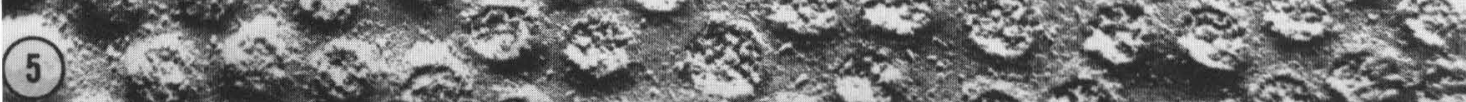

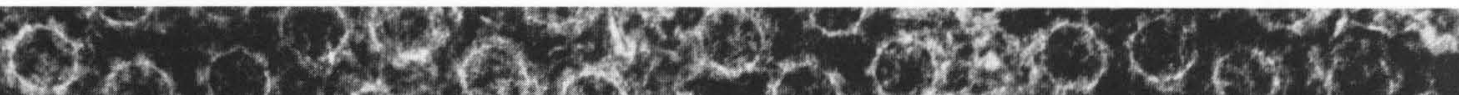

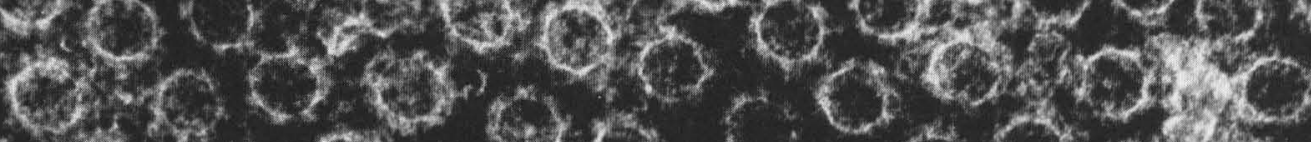

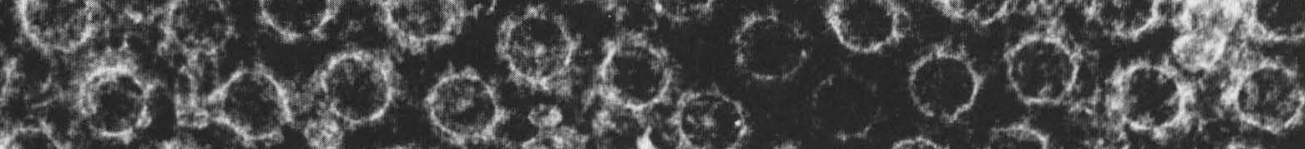

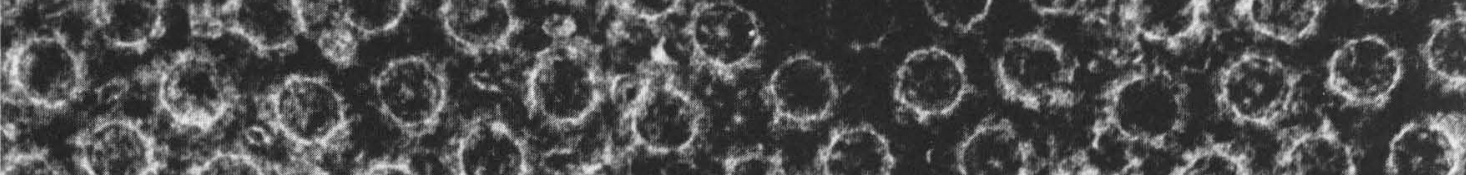
2.

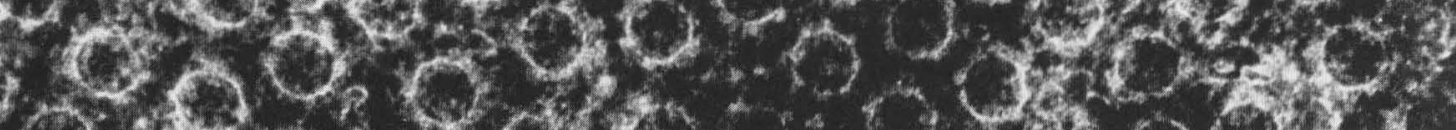

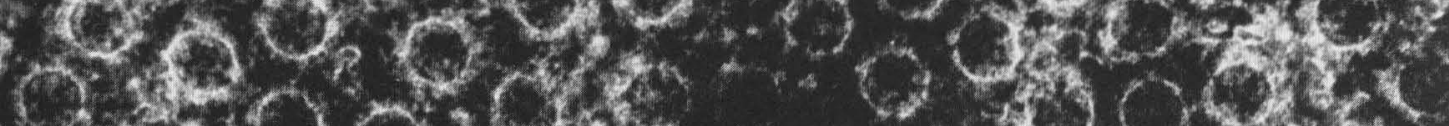

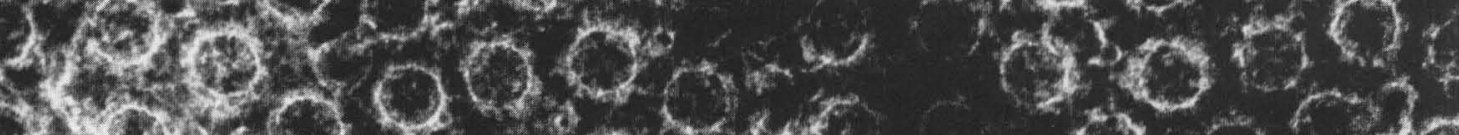
1960 00.

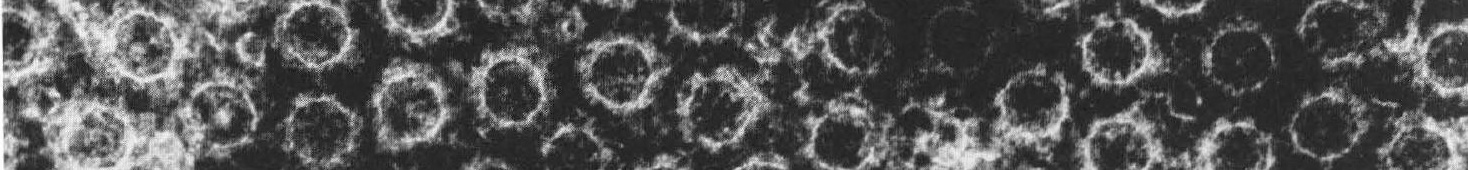

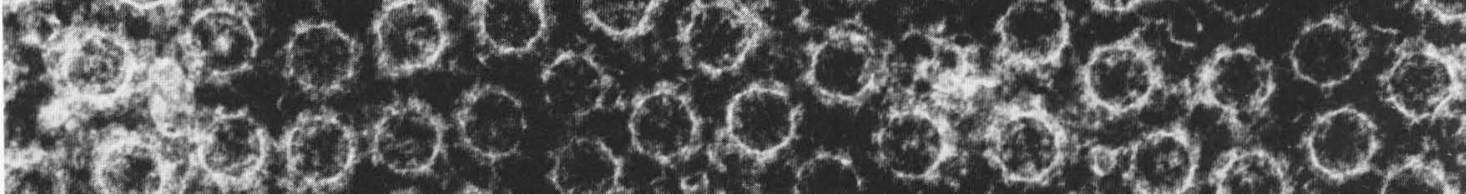
gow 20 .

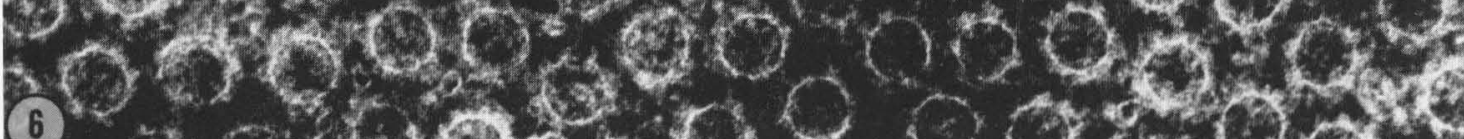
6. 
tions can be found in the literature that the nuclear envelope of germinal vesicles in growing amphibian oocytes increases in area through the development of irregular contours or saclike protrusions (e.g., Duryee, 1950; Kemp, 1956; Wischnitzer, 1967). As a consequence, the total nuclear surface should then be greater than the corresponding sphere surface. However, cryotome sections through frozen midlampbrush stage (e.g., Fig. 7) and mature Xenopus oocytes did not reveal marked serrations of the nuclear envelope, thus confirming the above assumption of an approximately spherical nucleus. ${ }^{3}$

During the oocyte growth from 300 to $1100 \mu \mathrm{m}$ diameter which lasts for 38 days (Fig. 3), the total number of nuclear pore complexes increases by 27.6 millions (Table 2, last column). The average de novo formation of nuclear pore complexes

${ }^{3}$ This does not rule out the possible occurrence of smaller invaginations not detectable on the light microscopic level. The present state of electron microscopic technique, however, does not allow an examination of the in vivo significance of such protrusions since no preparative method is known to work with amphibian oocytes which totally avoids dehydration shrinkage.

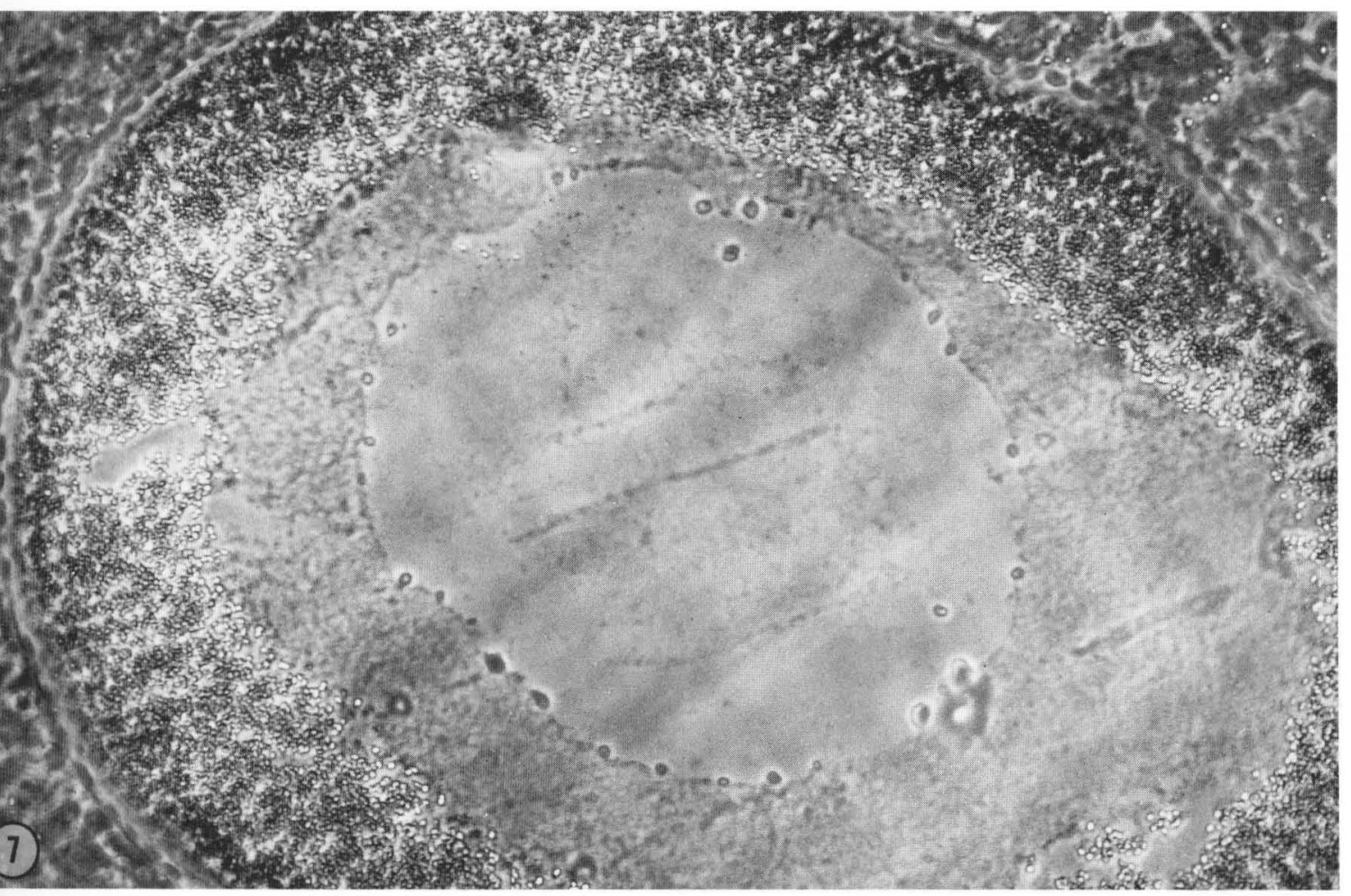

Fig. 7. Microphotograph of a cryotome section $(10 \mu \mathrm{m})$ through a frozen mid-lampbrush-stage Xenopus oocyte. Yolk platelets fill the outer half of the cytoplasm. The nuclear envelope, which is marked by numerous nucleoli attached to the inner nuclear membrane, appears smooth in circumference. $\times 270$.

Fig. 5. Freeze-etch aspect of fractured nuclear envelope of an intact Xenopus laevis lampbrush-stage oocyte. The pore margins are clearly visible. Note the high pore frequency which is in the same order of magnitude as that of negative staining preparations (see Fig. 6). $\times 73,800$.

Fig. 6. Isolated nuclear envelope of a lampbrush-stage Xenopus laevis oocyte (same stage as in Fig. 5), negatively stained with $2 \%$ phosphotungstic acid $(\mathrm{pH} 7.2)$. In this preparation the nonmembranous substructures, which build up a pore complex, are partially removed by the isolation step in bivalent cation-free medium to show the pore margins. $\times 73,800$. 
occurs at a rate of about 8 pores per second (for possible modes of such a formation compare Franke and Scheer, 1971).

\section{Nuclear Pore Flow Rate of Ribosomal RNA}

From Table 3 it can be seen that during oocyte development the translocation efficiency of a nuclear pore complex, quantified as the nuclear pore flow rate, shows considerable variations. The relatively low NPFR values during the early oogenesis intervals from 300 to $500 \mu \mathrm{m}$ oocyte diameter is due to the slow accumulation of cytoplasmic RNA (see Fig. 4), which may be caused either by a low transcriptional activity of the ribosomal genes or by a high intranuclear turnover rate of the rRNA species. However, the following stages (from 500 to $1100 \mu \mathrm{m}$ oocyte diameter) have a constant nucleocytoplasmic efflux rate of rRNA, independent of the nuclear size (Fig. 4). Since the total transport capacity of the nuclear envelope increases owing to the increasing number of pore complexes, the NPFR values progressively become lower. It is noteworthy that reduction of the translocation rate per nuclear pore complex in older oocyte stages is caused not by a lower transcriptional activity, but by the formation of new pore complexes.

Mature oocytes no longer accumulate
rRNA and show no transcriptional activity except in the final hormone-induced maturation period leading to ovulation (about $12 \mathrm{hr}$ ), in which a small amount of heterogeneous RNA is synthesized (Brown and Littna, 1964a). A mature and metabolically inert oocyte can remain for several months in this inactive state (e.g., Brown and Littna, 1964b). Although there is no outflow of RNA molecules from the nucleus into the cytoplasm, the transport capacity of the nuclear envelope, i.e., the number of pore complexes, is not reduced (Table 3). Obviously a high nuclear pore frequency is not necessarily indicative of a massive nucleocytoplasmic efflux of RNA.

\section{Chain Growth Rate of the Ribosomal RNA Precursor}

During the growth interval of a Xenopus oocyte in which its diameter increases from 300 to $1100 \mu \mathrm{m}$ in 38 days, $3.8 \mu \mathrm{g}$ of RNA are synthesized (Table 3). As will be discussed later, this RNA increase is almost totally caused by the accumulation of stable cytoplasmic ribosomes. Since one Xenopus ribosome has a RNA content of $3.7 \times 10^{-18} \mathrm{~g}$ (e.g., Loening et al., 1969), one oocyte nucleus synthesizes about 313,000 ribosomes in $1 \mathrm{sec}$ (for comparison, a rapidly growing somatic eukaryotic cell

TABLE 3

Nuclear Pore Flow Rate (NPfR) ${ }^{a}$ for Ribosomal RNA during the Growth Phase of Oogenesis and in Mature Oocytes of Xenopus laevis

\begin{tabular}{|c|c|c|c|c|c|}
\hline $\begin{array}{c}\text { Oogenesis } \\
\text { interval, oocyte } \\
\text { diameter } \\
(\mu \mathrm{m})\end{array}$ & $\begin{array}{l}\text { Mean total } \\
\text { number of pore } \\
\text { complexes per } \\
\text { nucleus at the } \\
\text { middle of the } \\
\text { oogenesis interval }\end{array}$ & $\begin{array}{c}\text { Duration of } \\
\text { oogenesis interval } \\
\text { (days) }\end{array}$ & $\begin{array}{l}\text { Increase of } \\
\text { cytoplasmic } \\
\text { rRNA } \\
\text { content } \\
(\mu \mathrm{g})\end{array}$ & $\begin{array}{l}\mathrm{NPFR}_{N} c \\
\left(10^{-18} \mathrm{~g}\right. \\
\text { rRNA/pore/ } \\
\text { min) }\end{array}$ & $\begin{array}{l}\mathrm{NPFR}_{\mathrm{N}} c \\
\text { (molecules } \\
\mathrm{rRNA}^{\text {minore/ }} \\
\mathrm{min}^{b}\end{array}$ \\
\hline $300-400$ & $12.2 \times 10^{6}$ & 12 & 0.252 & 1.20 & 0.66 \\
\hline $400-500$ & $16.1 \times 10^{6}$ & 7 & 0.533 & 3.28 & 1.80 \\
\hline $500-700$ & $20.7 \times 10^{6}$ & 7 & 1.0 & 4.79 & 2.62 \\
\hline $7 C 0-900$ & $27.6 \times 10^{6}$ & 6 & 0.95 & 3.98 & 2.18 \\
\hline $900-1100$ & $34.7 \times 10^{6}$ & 6 & 1.0 & 3.34 & 1.83 \\
\hline $\begin{array}{l}1200 \\
\text { (fully mature) }\end{array}$ & $37.7 \times 10^{6}$ & $\begin{array}{l}\text { Up to several } \\
\text { weeks or } \\
\text { months }\end{array}$ & $\sim 0$ & $\sim 0$ & $\sim 0$ \\
\hline
\end{tabular}

${ }^{a}$ NPFR values are given for the unidirectional translocation of rRNA from $\mathrm{N}$ (ucleus) to $\mathrm{C}$ (ytoplasm).

${ }^{b}$ Using a mean molecular weight of $1.1 \times 10^{6}$ for both $28 \mathrm{~S}$ and $18 \mathrm{~S}$ rRNAs $\left(1.5 \times 10^{6}\right.$ and $0.7 \times 10^{6}$, respectively; Loening et al., 1969). 
synthesizes $10-100$ ribosomes per second; e.g., Loening, 1970). This means that at least 313,000 pre-rRNA molecules (each of which contains the nucleotide sequences for both mature species) are transcribed per second in the extrachromosomal nucleoli of a germinal vesicle, assuming that each pre-rRNA synthesized is processed to final rRNAs.

Earlier sucrose gradient determinations of Gall (1966) and Rogers (1968) in Triturus and Ambystoma have demonstrated a $40 \mathrm{~S}$ RNA molecule as the primary transcription product of the extrachromosomal oocyte nucleoli. The gel electrophoresis of labeled RNA of nuclei from lampbrush stage oocytes of Xenopus laevis confirm these results and, in addition, allow a more precise determination of the molecular weight of the pre-rRNA (Fig. 8). Since the synthesis of nonribosomal RNA species is quantitatively negligible during the lampbrush stage of the amphibian oocyte system (e.g., Davidson et al., 1964), it is justified to regard the radioactive nuclear species with the highest molecular weight as the primary transcription product of the extrachromosomal rRNA cistrons $(2.5 \times$ $10^{6}$ daltons; standard error $=0.06$ ) .

If 313,000 pre-rRNA molecules with a molecular weight of $2.5 \times 10^{6}$ are transcribed per second, then about $2.3 \times 10^{9}$ nucleotides per second are assembled in one nucleus to yield the pre-rRNA. In a single Xenopus oocyte nucleus at least $67.5 \times 10^{6}$ polymerases are simultaneously transcribing the pre-rRNA (Miller and Beatty, 1969). With the use of this value, the chain growth rate of the precursor RNA molecule can be estimated to be approximately 34 nucleotides per second.

\section{DISCUSSION}

The calculations on the rRNA transport efficiency of a nuclear pore complex during oogenesis as summarized in Table 3 were based upon the determination of three different parameters: (1) increase of cytoplasmic rRNA content, (2) total number of pore complexes in different oogenesis phases, and (3) duration of oocyte growth.

1. It was assumed that the increase of the total acid-insoluble RNA content during oocyte growth is mainly due to the in-

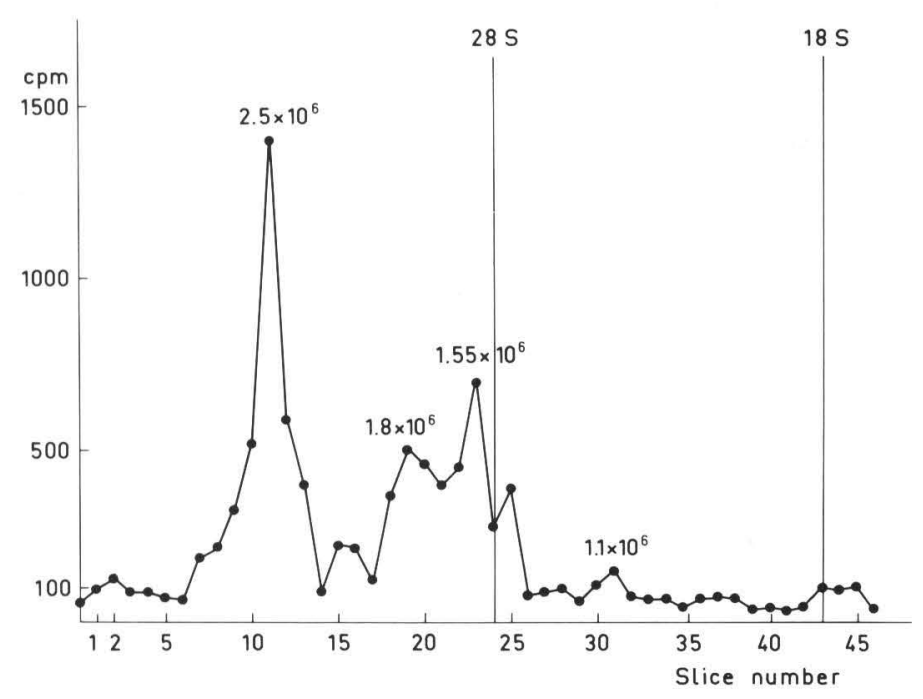

Fig. 8. Separation of ${ }^{3} \mathrm{H}$-uridine-labeled RNA of nuclei isolated from Xenopus laevis lampbrush-stage oocytes on an agarose-acrylamide composite gel. The lines denoted by $28 \mathrm{~S}$ and $18 \mathrm{~S}$ indicate the positions of nonlabeled cytoplasmic oocyte rRNAs run in the same gel for reference. Note the high molecular weight precursors of mature ribosomal RNAs, including the primary pre-rRNA (molecular weight $=2.5 \times 10^{6}$ ). Note also the near absence of $28 \mathrm{~S}$ and $18 \mathrm{~S}$ RNAs in the nucleus. 
crease in both $18 \mathrm{~S}$ and $28 \mathrm{~S}$ rRNAs in the ooplasm. This assumption is supported by the following findings. (a) At the lampbrush stage as well as in the mature state only $2-7 \%$ by mass of the Xenopus oocyte RNA is template-active (Davidson et al., 1966; Cape and Decroly, 1969). (b) During the lampbrush stage an average of $93 \%$ of the acid-insoluble RNA synthesis represents rRNA (Davidson et al., 1964). (c) Over $90 \%$ of the RNA in a mature oocyte consists of the $18 \mathrm{~S}$ and $28 \mathrm{~S}$ rRNAs (Mairy and Denis, 1971). (d) The values for total oocyte RNA (Table 1) are nearly identical with the ooplasmic RNA content since the acid-insoluble nuclear RNA amounts to only $0.5 \%$ of the total oocyte RNA in a mature oocyte (diameter 1.0-1.2 mm; Scheer, 1972), and to about $5 \%$ in the youngest stages examined (300-400 $\mu \mathrm{m}$ diameter). (e) Furthermore it is assumed that no degradation of the rRNA occurs during oogenesis (Brown, 1964, 1966; Davidson et al., 1964; Brown and Littna, 1964b), and (f), that all rRNA is synthesized in the nucleus. This latter postulation is supported by autoradiographic studies showing that at least the vast majority of RNA synthesis in amphibian oocytes is nuclear (e.g., Ficq, 1960; Davidson et al., 1964; Sanchez, 1969). The mitochondrial DNA can be excluded to code for rRNA since there exist no sequence homologies between either $18 \mathrm{~S}$ or $28 \mathrm{~S}$ rRNAs and mitochondrial DNA (Swanson and Dawid, 1970). (g) Nonnuclear RNA can be quantitatively neglected: one of the chief sources of nonnuclear RNA synthesis are the mitochondria, which contain $2.4 \times 10^{-9} \mathrm{~g}$ of DNA per Xenopus egg or $0.52 \mu \mathrm{g}$ of DNA per milligram of mitochondrial protein (Dawid, 1966). If one assumes a DNA: RNA ratio in mitochondria of about 1:4 (e.g., a rat liver mitochondrion contains ca. $2 \mu \mathrm{g}$ of RNA per milligram of protein; Kroon, 1969), then the total mitochondrial RNA content of a mature oocyte does not exceed ca. $0.01 \mu$ g, i.e., $0.24 \%$ of the total cyto- plasmic RNA (recently Dawid, 1972, reported a value of ca $1 \%$ ).

2. The pore frequency in amphibian oocytes has been shown to be largely independent of the preparation method used, namely negative staining, ultrathin sectioning, and freeze-etching (Kartenbeck et al., 1971). The only source of error in determining the total number of pore complexes per nucleus are deviations of the nuclear surface from a spherical shape. Light microscopy of cryotome sections through isolated and frozen oocytes, however, revealed no marked undulation of the nuclear periphery (see Results).

3. Under natural conditions oogenesis may take much more time than experimentally determined in this study. Normally, oocyte development seems to be repressed by the presence of a certain number of mature oocytes in the same ovary and can be induced only after completion of their ovulation.

From Table 3 it is obvious that during oogenesis differences exist in the RNA efflux rates. The average NPFR of the lampbrush-stage oocyte has a value comparable to that of other biological material, such as HeLa cells (Franke, 1970) and rat hepatocytes (Franke et al., 1971), but is much lower than that of the macronucleus of the ciliate Tetrahymena pyriformis during exponential growth (Franke, 1970). During the oocyte growth from $300 \mu \mathrm{m}$ diameter to the mature egg, the NPFR shows a maximum in mid-oogenesis (oocyte diameter $500-700 \mu \mathrm{m}$ ), i.e., the most pronounced lampbrush stage (cf. also Davidson et al., 1964). In younger stages the NPFR declines owing to a lower rRNA accumulation rate (Fig. 4). This result is in accordance with observations of Thomas (1970), Mairy and Denis (1971), and Denis and Mairy (1972) that small Xenopus oocytes (less than $250 \mu \mathrm{m}$ in diameter) contain very little $18 \mathrm{~S}$ and $28 \mathrm{~S}$ rRNA species but mainly low molecular weight RNAs (4 S to $5 \mathrm{~S}$ ). Thomas (1970) con- 
cluded that the nucleolar DNA in this period of growth, which precedes vitellogenesis, could be at least partially in a repressed state. In middle-sized oocytes from about 400 to $1100 \mu \mathrm{m}$ diameter the transcriptional activity then is constant (Fig. 4), while the NPFR values decrease slightly because of the increasing number of pore complexes per nucleus (Table 3). At the termination of oogenesis the synthesis of RNA is repressed and the NPFR values fall to zero.

In a previous paper the RNA content of one pore complex of an oocyte nucleus was determined with biochemical methods $\left(0.41 \times 10^{-16} \mathrm{~g}\right)$, and it was calculated that the substructures which make up one pore complex could contain about 20 rRNA molecules of a mean molecular weight of $1.1 \times 10^{6}$ in a membrane-bound state (Scheer, 1972). Assuming that during the lampbrush phase the pore complex elements represent dynamic structures with a certain steady-state RNA content, it can be calculated that one "average" rRNA molecule remains in a pore complex between $8 \mathrm{~min}$ (for a NPFR of 2.62 molecules $\mathrm{rRNA} /$ pore/min) and $30 \mathrm{~min}$ (NPFR of $0.66)$ before it is released into the cytoplasm. In contrast, the NPFR values in a maturing oocyte decrease to zero and, consequently, a ribosomal molecule remains for much longer time (or even becomes arrested) in the pore complex. From this one might ascribe to the ribonucleoprotein of the nuclear pore complex structures a dynamic nature in lampbrush-stage oocytes, but a stationary ("frozen") state when the NPFR value approach zero. Whether these pore complex-associated molecules represent the final rRNA species and/or intermediate forms of the processing sequence of the pre-rRNA is currently under investigation. Some observations suggest the final maturation of the $28 \mathrm{~S}$ rRNA taking place simultaneously with its transport into the cytoplasm (for Chironomus salivary glands: Ringborg and
Rydlander, 1971; for yeast: Sillevis Smitt et al., 1972). Furthermore, no mature rRNA species can be found in the nucleus of the amphibian oocyte (Gall, 1966; Rogers, 1968; compare also Fig. 8 of the present study).

The molecular weight of the primary transcription product of the ribosomal cistrons in the extrachromosomal nucleoli of Xenopus oocytes was determined by agarose-acrylamide composite gel electrophoresis to be $2.5 \times 10^{6}$ daltons. This fairly agrees with the earlier sucrose gradient determinations in Triturus viridescens by Gall (1966). The pre-rRNA of the extrachromosomal rRNA cistrons is of the same size as the corresponding rRNA precursor made on the chromosomal nucleolus organizer of somatic amphibian cells (for Xenopus laevis cells: $2.5 \times 10^{6}$ daltons, Birnstiel et al., 1968; Loening et al., 1969; for Rana pipiens cells: $2.7 \times 10^{6}$ daltons, Perry et al., 1970). This result suggests that both chromosomal and amplified rRNA cistrons are identical (compare also Dawid et al., 1970; Wensink and Brown, 1971). The electrophoretic separation of the oocyte nuclear RNA species showed two components slightly heavier than the $28 \mathrm{~S}$ reference rRNA with molecular weights about $1.8 \times 10^{6}$ and $1.55 \times 10^{6}$ (Fig. 8). Similar RNA species also had been found in Xenopus kidney cells $\left(1.78 \times 10^{6}\right.$ and $1.63 \times 10^{6}$ daltons, respectively; Loening et al., 1969). Furthermore, a slight radioactivity peak corresponding to a molecular weight of about $1.1 \times 10^{6}$ was visible in the electropherograms (Fig. 8), which is comparable to the $20 \mathrm{~S}$ RNA found by Rogers (1968) in urodelen oocytes. A $20 \mathrm{~S}$ RNA is thought to be the immediate precursor of the $18 \mathrm{~S}$ rRNA in mammalian cell systems (e.g., Grierson et al., 1970; Loening, 1970; Weinberg and Penman, 1970).

For the calculation of the chain growth rate of the pre-rRNA it was assumed that for one precursor transcribed finally a $18 \mathrm{~S}$ 
and $28 \mathrm{~S}$ rRNA molecule is released into the ooplasm. The average value of $34 \mathrm{nu}-$ cleotides per second for the elongation rate of a precursor molecule during oogenesis may be underestimated in case the proportion of the pre-rRNA which is successfully processed to mature rRNAs is less (for discussion see Fantoni and Bordin, 1971). Anyway, this value is in good agreement with other growth rates reported for transcription of ribosomal RNA cistrons in eukaryotic cells such as in HeLa cells (ca. 90 nucleotides per second; Greenberg and Penman, 1966) and in Euglena gracilis (12.5 nucleotides per second; Brown and Haselkorn, 1971). It is also in the range reported for prokaryotic systems (e.g., Manor et al., 1969).

The author is indebted to Miss Marianne Winter, Mrs. E. Boichut-Laube, and Miss Sigrid Krien for skillful technical assistance. I thank Dr. B. Daneholt (Karolinska Institutet, Stockholm, Sweden) for introduction into the techniques of RNA electrophoresis, and Dr. W. W. Franke for valuable discussions and support (Deutsche Forschungsgemeinschaft and SFB 46, Molekulare Grundlagen der Entwicklung, Freiburg i. Br.).

\section{REFERENCES}

Balinsky, B. I., and Devis, R. J. (1963). Origin and differentiation of cytoplasmic structures in the oocytes of Xenopus laevis. Acta Embryol. Morphol. Exp. 6, 55-108.

Birnstiel, M., Speirs, J., Purdom, I., Jones, K., and Loening, U. E. (1968). Properties and composition of the isolated ribosomal DNA satellite of Xenopus laevis. Nature (London) 219, 454-463.

Brown, D. D. (1964). RNA synthesis during amphibian development. J. Exp. Zool. 157, 101-114.

Brown, D. D. (1966). The nucleolus and synthesis of ribosomal RNA during oogenesis and embryogenesis of Xenopus laevis. Nat. Cancer Inst. Monogr. 23, 297-309.

Brown, D. D. (1967). Nucleic acid determination in embryos. In "Methods in Developmental Biology" (F. H. Wilt and N. K. Wessells, eds.), pp. 685-701. Crowell-Collier, New York.

Brown, D. D., and Dawid, I. B. (1968). Specific gene amplification in oocytes. Science 160, 272-280.

Brown, D. D., and LitTnA, E. (1964a). RNA synthesis during the development of Xenopus laevis, the South African clawed toad. J. Mol. Biol. 8, 669687.

Brown, D. D., and Littna, E. (1964b). Variations in the synthesis of stable RNA's during oogenesis and development of Xenopus laevis. J. Mol. Biol. 8, 688-695.

Brown, R. D., and Haselkorn, R. (1971). Synthesis and maturation of cytoplasmic ribosomal RNA in Euglena gracilis. J. Mol. Biol. 59, 491-503.

Callan, H. G. (1963). The nature of lampbrush chromosomes. Int. Rev. Cytol. 15, 1-34.

Callan, H. G., and Lloyd, L. (1960). Lampbrush chromosomes of crested newts Triturus cristatus (Laurenti). Phil. Trans. Roy. Soc. (London) Ser. B, 243, 135-219.

Cape, M., and Decroly, M. (1969). Mesure de la capacité "template" des acides ribonucléiques des oeufs de Xenopus laevis au cours du développement. Biochim. Biophys. Acta 174, 99-107.

Clerot, J. C. (1968). Mise en évidence par cytochimie ultrastructurale de l'émission de protéines par le noyau d'auxocytes de batraciens. J. Microsc. (Paris) 7, 973-992.

Cole, M. B. (1969). Ultrastructural cytochemistry of granules associated with the nuclear pores of frog oocytes. J. Cell Biol. 43, 24a-25a.

Cox, R. A., Ford, P. J., and Pratr, H. (1970). Ribosomes from Xenopus laevis ovaries and the polyuridylic acid-directed biosynthesis of polyphenylalanine. Biochem. J. 119, 161-164.

Davidson, E. H. (1968). "Gene Activity in Early Development." Academic Press, New York.

Davidson, E. H., Allfrey, V. G., and Mirsky, A. E. (1964). On the RNA synthesized during the lampbrush phase of amphibian oogenesis. Proc. Nat. Acad. Sci. U.S. 52, 501-508.

Davidson, E. H., Crippa, M., Kramer, F. R., and Mirsky, A. E. (1966). Genomic function during the lampbrush chromosome stage of amphibian oogenesis. Proc. Nat. Acad. Sci. U.S. 56, 856-863.

Dawid, I. B. (1966). Evidence for the mitochondrial origin of frog egg cytoplasmic DNA. Proc. Nat. Acad. Sci. U.S. 56, 269-276.

DAwID, I. B. (1972). Mitochondrial RNA in Xenopus laevis. I. The expression of the mitochondrial genome. J. Mol. Biol. 63, 201-216.

Dawid, I. B., Brown, D. D., and Reeder, R. H. (1970). Composition and structure of chromosomal and amplified ribosomal DNAs of Xenopus laevis. J. Mol. Biol. 51, 341-360.

Denis, H., and MaIRY, M. (1972). Recherches biochimiques sur l'oogenèse. 1. Distribution intracellulaire du RNA dans les petits oocytes de Xenopus laevis. Eur. J. Biochem. 25, 524-534.

DuryeE, W. R. (1950). Chromosomal physiology in relation to nuclear structure. Ann. N. Y. Acad. Sci. 50, 920-942.

EdDy, E. M., and Iтo, S. (1971). Fine structural and radioautographic observations on dense perinuclear cytoplasmic material in tadpole oocytes. $J$. Cell Biol. 49, 90-108. 
Fantoni, A., and Bordin, S. (1971). Passage of ribosomal RNA from nucleus to cytoplasm in differentiating yolk sac erythroid cells. Biochim. Biophys. Acta 238, 245-258.

FicQ, A. (1960). Métabolisme de l'oogenèse chez les amphibians. "Symposium on germ cells and development," pp. 121-140. Inst. Int. d'Embriol., Fondazione A. Baselli, Milan.

FicQ, A. (1968). Synthesis and detection of DNA in early oogenesis. Exp. Cell Res. 53, 691-693.

Franke, W. W. (1970). Nuclear pore flow rate. Naturwissenschaften 57, 44-45.

Franke, W. W., and Scheer, U. (1970a). The ultrastructure of the nuclear envelope of amphibian oocytes: a reinvestigation. I. The mature oocyte. J. Ultrastruct. Res. 30, 288-316.

Franke, W. W., and Scheer, U. (1970b). The ultrastructure of the nuclear envelope of amphibian oocytes: a reinvestigation. II. The immature oocyte and dynamic aspects. J. Ultrastruct. Res. 30, 317-327.

Franke, W. W., and Scheer, U. (1971). Some structural differentiations in the HeLa cell: heavy bodies, annulate lamellae, and cotte de maille endoplasmic reticulum. Cytobiology 4, 317-329.

Franke, W. W., Kartenbeck, J., and Deumling, B. (1971). Nuclear pore flow rates of ribonucleic acids in the mature rat hepatocyte. Experientia 27, 372373.

GaLL, J. G. (1966). Nuclear RNA of the salamander oocyte. Nat. Cancer Inst. Monogr. 23, 475-468.

Gall, J. G., and Callan, H. G. (1962). $\mathrm{H}^{3}$-uridine incorporation in lampbrush chromosomes. Proc. Nat. Acad. Sci. U.S. 48, 562-570.

Gerlach, E., and Deuticke, B. (1963). Eine einfache Methode zur Mikrobestimmung von Phosphat in der Papierchromatographie. Biochem. Z. 337, 477-479.

Grant, P. (1953). Phosphate metabolism during oogenesis in Rana temporaria. J. Exp. Zool. 124, 513543.

Greenberg, H., and Penman, S. (1966). Methylation and processing of ribosomal RNA in HeLa cells. J. Mol. Biol. 21, 527-535.

Grierson, D., Rogers, M. E., Sartirana, M. L., and LoEning, U. E. (1970). The synthesis of ribosomal RNA in different organisms: structure and evolution of the rRNA precursor. Cold Spring Harbor Symp. Quant. Biol. 35, 589-598.

HanocQ-Quertier, J., Baltus, E., FicQ, A., and Brachet, J. (1968). Studies on the DNA of Xenopus laevis oocytes. J. Embryol. Exp. Morphol. 19, 273-282.

Hotta, Y., and Bassel, A. (1965). Molecular size and circularity of DNA in cells of mammals and higher plants. Proc. Nat. Acad. Sci. U.S. 53, 356-362.

Jared, D. W., and Wallace, R. A. (1970). Protein uptake in vitro by amphibian oocytes. Exp. Cell
Res. 57, 454-457.

Kartenbeck, J., Zentgraf, H., Scheer, U., and Franke, W. W. (1971). The nuclear envelope in freeze-etching. Advan. Anat. Embryol. Cell Biol. 45, 1-55.

Kelley, R. O., Nakai, G. S., and Guganig, M. E. (1970). Biochemical and ultrastructural evidence of RNA in yolk platelets of Xenopus gastrulae. J. Cell Biol. 47, 103a-104a.

KeMP, N. E. (1956). Electron microscopy of growing oocytes of Rana pipiens. J. Biophys. Biochem. Cytol. 2, 281-291.

Kessel, R. G. (1969). Cytodifferentiation in the Rana pipiens oocyte. I. Association between mitochondria and nucleolus-like bodies in young oocytes. $J$. Ultrastruct. Res. 28, 61-77.

Kroon, A. M. (1969). DNA and RNA from mitochondria and chloroplasts. In "Handbook of Molecular Cytology” (A. Lima-De-Faria, ed.), pp. 943-971. North-Holland Publ., Amsterdam.

LANE, N. J. (1967). Spheroidal and ring nucleoli in amphibian oocytes. Patterns of uridine incorporation and fine structural features. J. Cell Biol. 35, 421-434.

Loening, U. E. (1970). The mechanisms of synthesis of ribosomal RNA. Symp. Soc. Gen. Microbiol. 20, 77-106.

Loening, U. E., Jones, K. W., and Birnstiel, M. L. (1969). Properties of the ribosomal RNA precursor in Xenopus laevis: comparison to the precursor in mammals and in plants. J. Mol. Biol. 45, 353-366.

MaIRY, M., and Denis, H. (1971). Recherches biochimiques sur l'oogenèse. I. Synthèse et accumulation du RNA pendant l'oogenèse du crapaud sudafricain Xenopus laevis. Develop. Biol. 24, 143165.

Manor, H., Goodman, D., and Stent, G. S. (1969). RNA chain growth rates in Escherichia coli. $J$. Mol. Biol. 39, 1-29.

Massover, W. H. (1968). Cytoplasmic cylinders in bullfrog oocytes. J. Ultrastruct. Res. 22, 159-167.

Miller, O. L. (1962). Studies on the ultrastructure and metabolism of nucleoli in amphibian oocytes. Proc. Int. Congr. Electron Microsc. 5th, NN-8.

Miller, O. L., and Beatty, B. R. (1969). Extrachromosomal nucleolar genes in amphibian oocytes. Genetics, Suppl., 61, 134-143.

Osawa, S., and Hayashi, Y. (1953). Ribonucleic acid and protein in the growing oocytes of Triturus pyrrhogaster. Science 118, 84-86.

PanJe, W. R., and Kessel, R. G. (1968). Soluble proteins and quantitative analysis of protein and RNA during oogenesis in Necturus maculosus. Exp. Cell Res. 51, 313-322.

Perry, R. P., Cheng, T. Y., Freed, J. J., GreenBerg, J. R., Kelley, D. E., and Tartof, K. D. (1970). Evolution of the transcription unit of ribosomal RNA. Proc. Nat. Acad. Sci. U.S. 65, 609- 
616.

Peterson, A. W. (1971). Relationship between germinal vesicle volume and cytoplasmic volume in amphibian oocytes. Can. J. Genet. Cytol. 13, 898-901.

Pollister, A. W., Gettner, M., and Ward, R. (1954). Nucleocytoplasmic interchange in oocytes. Science 120, 789.

Raven. O. P. (1961). “Oogenesis.” Pergamon, Oxford.

Ringborg, U., and Rydlander, L. (1971). Nucleolar derived RNA in chromosomes, nuclear sap and cytoplasm of Chironomus tentans salivary gland cells. J. Cell Biol. 51, 355-368.

Ringborg, U., Daneholt, B., Edströ, J. E., EgyHAZI, E., and LAMBERT, B. (1970). Electrophoretic characterization of nucleolar RNA from Chironomus tentans salivary gland cells. J. Mol. Biol. 51, 327-340.

Rogers, M. E. (1968). Ribonucleoprotein particles in the amphibian oocyte nucleus. J. Cell Biol. 36, 421432.

Sanchez, S. (1969). Formation et rôle des nucléoles des ovocytes de Triturus helveticus Raz.-Etude autoradiographique et ultramicroscopique. J. Embryol. Exp. Morphol. 22, 127-143.

SCHEER, U. (1972). The ultrastructure of the nuclear envelope of amphibian oocytes. IV. On the chemical nature of the nuclear pore complex material. Z. Zellforsch. Mikrosk. Anat.' 127, 127-148.

Scheer, U., and Franke, W. W. (1969). Negative staining and adenosine triphosphatase activity of annulate lamellae of newt oocytes. J. Cell Biol. 42, 519-533.

Sillevis Smitt, W. W., Vlak, J. M., Schiphof, R., and Rozisn, T. H. (1972). Precursors of ribosomal
RNA in yeast nucleus. Exp. Cell Res. 71, 33-40.

Swanson, R. F., and Dawid, I. B. (1970). The mitochondrial ribosome of Xenopus laevis. Proc. Nat. Acad. Sci. U.S. 66, 117-124.

ТАкамото, Т. (1966). Ultrastructural transport mechanism of messenger RNA in the young oocytes of amphibians. Nature (London) 211, 772-773.

Tномаs, C. (1970). Ribonucleic acids and ribonucleoproteins from small oocytes of Xenopus laevis. Biochim. Biophys. Acta 224, 99-113.

Wallace, R. A. (1970). Studies on amphibian yolk. IX. Xenopus vitellogenin. Biochim. Biophys. Acta 215, 176-183.

Wallace, R. A., and Dumont, J. N. (1968). The induced synthesis and transport of yolk proteins and their accumulation by the oocyte in Xenopus laevis. J. Cell Physiol. 72, Suppl., 73-89.

Wallace, R. A., and Jared, D. W. (1969). Studies on amphibian yolk. VIII. The estrogen-induced hepatic synthesis of a serum lipophosphoprotein and its selective uptake by the ovary and transformation into yolk platelet proteins in Xenopus laevis. Develop. Biol. 19, 498-526.

Weinberg, R. A., and Penman, S. (1970). Processing of $45 \mathrm{~S}$ nucleolar RNA. J. Mol. Biol. 47, 169-178.

Wensink, P. C., and Brown, D. D. (1971). Denaturation map of the ribosomal DNA of Xenopus laevis. J. Mol. Biol. 60, 235-247.

Wischnitzer, S. (1966). The ultrastructure of the cytoplasm of the developing amphibian egg. Advan. Morphog. 5, 131-179.

Wischnitzer, S. (1967). The ultrastructure of the nucleus of the developing amphibian egg. Advan. Morphog. 6, 173-198. 